\title{
Gracilibacillus lacisalsi sp. nov., a halophilic Gram- positive bacterium from a salt lake in China
}

\author{
Che Ok Jeon, ${ }^{1}$ Jee-Min Lim, ${ }^{2}$ Ho Hee Jang, ${ }^{3}$ Dong-Jin Park, ${ }^{2}$ Li-Hua Xu, ${ }^{4}$ \\ Cheng-Lin Jiang ${ }^{4}$ and Chang-Jin Kim² \\ ${ }^{1}$ Department of Life Science, Chung-Ang University, Seoul 156-756, Republic of Korea \\ ${ }^{2}$ Korea Research Institute of Bioscience and Biotechnology, 52 Oeundong, Yusong, Daejeon 305- \\ 333, Republic of Korea \\ ${ }^{3}$ Environmental Biotechnology National Core Research Center, Gyeongsang National University, \\ Jinju 660-701, Republic of Korea \\ ${ }^{4}$ Yunnan Institute of Microbiology, Yunnan University, Kunming, Yunnan 650091, PR China
}

Correspondence

Chang-Jin Kim

changjin@kribb.re.kr
Two Gram-positive, motile, rod-shaped, halophilic bacteria showing optimum growth at 5-7\% $(\mathrm{w} / \mathrm{v}) \mathrm{NaCl}$ were isolated from a salt lake, Xin-Jiang Province, China. The strains, designated $\mathrm{BH} 312^{\top}$ and $\mathrm{BH} 314$, grew in the presence of $1-18 \%(\mathrm{w} / \mathrm{v}) \mathrm{NaCl}$ and at temperatures of 15$50{ }^{\circ} \mathrm{C}$ (optimum: $40{ }^{\circ} \mathrm{C}$ ) and $\mathrm{pH}$ values of 5.5-10.0 (optimum: $\mathrm{pH} 7.5-8.0$ ). The major cellular fatty acids were anteiso- $\mathrm{C}_{15: 0}$, iso- $\mathrm{C}_{15: 0}$ and anteiso- $\mathrm{C}_{17: 0}$. The DNA G+C content was 38.8$39.0 \mathrm{~mol} \%$ and the predominant lipoquinone was MK-7. The major cellular phospholipids were phosphatidylglycerol, diphosphatidylglycerol and two unidentified phospholipids. Phylogenetic analyses based on 16S rRNA gene sequences showed that the isolates formed a cluster with Gracilibacillus orientalis $\mathrm{XH}-63^{\top}$ within the genus Gracilibacillus. The levels of $16 \mathrm{~S}$ rRNA gene sequence similarity with closely related type strains were lower than $96.2 \%$. On the basis of phylogenetic, phenotypic and chemotaxonomic properties, the isolates represent a novel species of the genus Gracilibacillus for which the name Gracilibacillus lacisalsi sp. nov. is proposed. The type strain is $\mathrm{BH} 312^{\top}\left(=\mathrm{KCTC} 13129^{\top}=\mathrm{DSM} 19029^{\top}\right)$.
Moderately halophilic bacteria that grow optimally in media containing 3-15\% (w/v) $\mathrm{NaCl}$ are widely distributed in different marine environments and are made up of very heterogeneous physiological groups taxonomically, including both Gram-positive and Gram-negative microorganisms (Ventosa et al., 1998; Oren, 2002; Jeon et al., 2005a; Lim et al., 2005). Aerobic, spore-forming, halophilic, Gram-positive rods that were originally assigned to the genus Bacillus are also very diverse taxonomically and they form several phylogenetically distinct lineages (Ash et al., 1991; Stackebrandt \& Liesack, 1993; Nielsen et al., 1994; Jeon et al., 2005b). Among them, the genus Gracilibacillus was first proposed by Wainø et al. (1999) to accommodate Gracilibacillus halotolerans, isolated from the Great Salt

Abbreviations: ML, maximum-likelihood; MP, maximum-parsimony; $\mathrm{NJ}$, neighbour-joining.

The GenBank/EMBL/DDBJ accession numbers for the 16S rRNA gene sequences of strains $\mathrm{BH} 312^{\top}$ and $\mathrm{BH} 314$ are $\mathrm{DQ664540}$ and D0664541, respectively.

A transmission electron micrograph showing general morphology of negatively stained cells of strain $\mathrm{BH} 312^{\top}$ and thin-layer chromatograms of polar lipids from strain $\mathrm{BH} 312^{\top}$ and related strains are available as supplementary material with the online version of this paper.
Lake, Utah (USA), and Gracilibacillus dipsosauri, transferred from Bacillus dipsosauri. Currently, the genus includes only four species: G. halotolerans, G. dipsosauri (Wainø et al., 1999), G. orientalis (Carrasco et al., 2006) and G. boraciitolerans (Ahmed et al., 2007). In the course of screening sediment of Ai-Ding Lake, Xin-Jiang Province, China, to isolate halophilic bacteria, two aerobic, Gram-positive, moderately halophilic bacteria, strains $\mathrm{BH} 312^{\mathrm{T}}$ and $\mathrm{BH} 314$, were isolated. Ai-Ding Lake $\left(42^{\circ} 32^{\prime} 10^{\prime \prime}-42^{\circ} 49^{\prime} 13^{\prime \prime} \mathrm{N} 89^{\circ} 10^{\prime} 32^{\prime \prime}-89^{\circ} 54^{\prime}\right.$ $\left.32^{\prime \prime} \mathrm{E}\right)$ is located in the most arid area of China, where evaporation is significantly higher than precipitation. The lake is the lowest point in China (154 m below sea-level) and has been a target area for the study of halophilic microorganisms for many years. Water is largely supplied from the nearby glacier of Tian-Shan Mountain. Ai-Ding Lake is a typical chloride-sulfate saline lake with a slightly alkaline $\mathrm{pH}$ (7.2-7.6) and a salt concentration of $20-26 \%(\mathrm{w} / \mathrm{v})$. The content of $\mathrm{Mg}^{2+}$ and $\mathrm{Ca}^{2+}$ in the brine is very low. On the basis of phylogenetic and phenotypic characteristics, strains $\mathrm{BH} 312^{\mathrm{T}}$ and $\mathrm{BH} 314$ have been classified as representatives of a novel species of the genus Gracilibacillus.

Samples were collected from sediment near the lake bank and packed in ice $\left(0{ }^{\circ} \mathrm{C}\right)$ before transportation to the 
laboratory. The samples were serially diluted using saline solution $(0.9 \%, \mathrm{w} / \mathrm{v})$, spread on marine agar 2216 (MA; Difco) with the addition of $10 \%(\mathrm{w} / \mathrm{v}) \mathrm{NaCl}$ [final concentration of $11.94 \% \mathrm{NaCl}(\mathrm{w} / \mathrm{v})]$ and incubated for 2 days at $35{ }^{\circ} \mathrm{C}$. After isolation, the isolates were cultivated at $40{ }^{\circ} \mathrm{C}$ for 2 days in marine broth (MB; Difco) with the addition of $3 \%(\mathrm{w} / \mathrm{v}) \mathrm{NaCl}$ and stored at $-80{ }^{\circ} \mathrm{C}$ in $\mathrm{MB}$ supplemented with $10 \%(\mathrm{v} / \mathrm{v})$ glycerol. Except where indicated, the isolates were routinely grown aerobically on MA with the addition of $3 \%(\mathrm{w} / \mathrm{v}) \mathrm{NaCl}$ for 2 days at $40{ }^{\circ} \mathrm{C} . \mathrm{NaCl}$ requirements and tolerance were determined by using nutrient broth (NB: $3.0 \mathrm{~g}$ beef extract $\mathrm{l}^{-1}$ and $5.0 \mathrm{~g}$ peptone $1^{-1}$ ) (Difco) with different concentrations $(0-20 \%, w / v)$ of $\mathrm{NaCl}$. Optimum growth at different temperatures $\left(5-55{ }^{\circ} \mathrm{C}\right.$ at $5{ }^{\circ} \mathrm{C}$ intervals) and $\mathrm{pH}$ values (5.0-11.0 at $0.5 \mathrm{pH}$ unit intervals) was tested in $\mathrm{MB}$ with the addition of $3 \%(\mathrm{w} / \mathrm{v}) \mathrm{NaCl}$. Media with different $\mathrm{pH}$ values were prepared using appropriate biological buffers: $\mathrm{Na}_{2} \mathrm{HPO}_{4}-\mathrm{NaH}_{2} \mathrm{PO}_{4}$ buffer, $\mathrm{Na}_{2} \mathrm{CO}_{3}-\mathrm{NaHCO}_{3}$ buffer and $\mathrm{Na}_{2} \mathrm{HPO}_{4}-\mathrm{NaOH}$ buffer were used for $\mathrm{pH}$ values below 8.0, $\mathrm{pH}$ 8.0-10.0 and pH 11.0, respectively (Gomori, 1955). Anaerobic growth was determined by incubation in an anaerobic chamber at $40{ }^{\circ} \mathrm{C}$ for 5 days on MA with the addition of $3 \%(\mathrm{w} / \mathrm{v}) \mathrm{NaCl}$. Gram staining was determined using the bioMérieux Gram Stain kit according to the manufacturer's instructions. Catalase activity was determined by bubble production in $3 \%(\mathrm{v} / \mathrm{v})$ aqueous hydrogen peroxide solution. Oxidase activity was tested using a strip containing tetramethyl-p-phenylenediamine (Merck). Nitrate reduction and hydrolysis of starch, aesculin, urea, casein, Tween 80, hypoxanthine and xanthine were determined according to methods described previously (Lányí, 1987; Smibert \& Krieg, 1994). Acid production from carbohydrates was determined as described by Leifson (1963); all suspension media were supplemented with $5 \%$ (w/v) $\mathrm{NaCl}$. Additional enzymic activities were determined using API ZYM (bioMérieux) at $40{ }^{\circ} \mathrm{C}$ as recommended by the manufacturer. Cell morphology and motility were studied using phase-contrast microscopy and transmission electron microscopy (JEM-1010; JEOL) as described by Jeon et al. (2005a). For visualization of the flagella, cells were mounted on Formvar-coated copper grids (Electron Microscopy Science) and negatively stained with $2 \%(\mathrm{w} / \mathrm{v})$ uranyl acetate for $15 \mathrm{~s}$, then subjected to transmission electron microscopy operating at $60 \mathrm{kV}$. Endospores were stained according to the method of Schaeffer-Fulton (Smibert \& Krieg, 1994). Strains $\mathrm{BH} 312^{\mathrm{T}}$ and $\mathrm{BH} 314$ formed cream, smooth, convex and circular/slightly irregular colonies when grown on MA with the addition of $3 \%$ (w/v) $\mathrm{NaCl}$ at $40{ }^{\circ} \mathrm{C}$ for 2 days. Cells of the isolates were motile, short rods with non-polar amphitrichous flagella after 2 days incubation at $40{ }^{\circ} \mathrm{C}$ (see Supplementary Fig. S1 in IJSEM Online). Strains $\mathrm{BH} 312^{\mathrm{T}}$ and $\mathrm{BH} 314$ showed the same phenotypic properties (Table 1), indicating that they may not be diverse physiologically.

For quantitative analysis of whole-cell fatty acids, strains $\mathrm{BH} 312^{\mathrm{T}}$ and $\mathrm{BH} 314$ were cultivated on MA containing 3.5 or $5.0 \%(\mathrm{w} / \mathrm{v}) \mathrm{NaCl}$ and on $\mathrm{MH}$ agar (Carrasco et al., 2006) containing $10 \%(\mathrm{w} / \mathrm{v}) \mathrm{NaCl}$ for 2 days at $35{ }^{\circ} \mathrm{C}$. GC analysis of fatty acid methyl esters was performed according to the instructions of the Microbial Identification System (MIDI; Microbial ID). Analyses of polar lipids and isoprenoid quinones were carried out using the methods described by Komagata \& Suzuki (1987). The DNA G + C content of the isolates was determined by reverse-phase HPLC (Hewlett Packard series II 1090) using the method of Tamaoka \& Komagata (1984). The fatty acid profiles of the strains were characterized by the presence of saturated fatty acids such as anteiso- $\mathrm{C}_{15: 0}$, iso- $\mathrm{C}_{15: 0}$ and anteiso$\mathrm{C}_{17: 0}$ as the major fatty acids. The fatty acid profiles of the isolates were similar to those of other related type strains in the genus Gracilibacillus (Table 2). The major isoprenoid quinone was menaquinone-7 (MK-7). Strain $\mathrm{BH} 312^{\mathrm{T}}$ contained phosphatidylglycerol, diphosphatidylglycerol and two unidentified phospholipids as the major polar lipids, but phosphatidylethanolamine was not detected in this strain, which had a similar polar lipid pattern to those of Gracilibacillus halotolerans $\mathrm{NN}^{\mathrm{T}}$ and Gracilibacillus dipsosauri $\mathrm{DD}^{\mathrm{T}}$ (see Supplementary Fig. S2 in IJSEM Online). The genomic DNA $\mathrm{G}+\mathrm{C}$ contents of strains $\mathrm{BH} 312^{\mathrm{T}}$ and $\mathrm{BH} 314$ were 39.0 and $38.8 \mathrm{~mol} \%$, respectively. The major fatty acid profile, the major lipoquinone and the major polar lipids of strains $\mathrm{BH} 312^{\mathrm{T}}$ and $\mathrm{BH} 314$ were typical of those of members of the genus Gracilibacillus (Wainø et al., 1999; Carrasco et al., 2006; Ahmed et al., 2007). Typical phenotypic and chemotaxonomic properties of strain $\mathrm{BH} 312^{\mathrm{T}}$ and $\mathrm{BH} 314$ are compared with those of phylogenetically related relatives in Table 1 . Some of them are in accordance with characteristics of members of the genus Gracilibacillus, whereas others enable the differentiation of strains $\mathrm{BH} 312^{\mathrm{T}}$ and $\mathrm{BH} 314$ from closely related Gracilibacillus species.

Sequencing of the 16S rRNA genes was carried out as described previously (Lane, 1991). The resulting 16S rRNA gene sequences of strains $\mathrm{BH} 312^{\mathrm{T}}$ and $\mathrm{BH} 314$ were compared with available 16S rRNA gene sequences from GenBank using the BLAST program (NCBI; http:// www.ncbi.nlm.nih.gov/BLAST/) to determine the approximate phylogenetic affiliation. Gene sequences were aligned with those of closely related species by using the software CLUSTAL W (Thompson et al., 1994). Phylogenetic trees were constructed using three different methods, i.e. neighbourjoining (NJ), maximum-likelihood (ML) and maximumparsimony (MP) algorithms available in the PHYLIP software, version 3.6 (Felsenstein, 2002). Evolutionary distance matrices were calculated according to the algorithm of the Kimura two-parameter model (Kimura, 1980 ) for the NJ method. Using the FASTA3 program in EBI, $16 \mathrm{~S}$ rRNA gene sequence comparisons were made between the novel strains and other members of the genus Gracilibacillus for similarity calculations. To evaluate the stability of the phylogenetic tree, bootstrap analysis (1000 replications) was performed with the programs SEQBOOT, DNADIST, NEIGHBOR and CONSENSE in the PHYLIP package. 
Table 1. Characteristics of Gracilibacillus lacisalsi sp. nov. and some related species

Species/strains: 1, Gracilibacillus lacisalsi sp. nov. (this study); 2, Gracilibacillus boraciitolerans T-16X ${ }^{\mathrm{T}}$ (Ahmed et al., 2007); 3, Gracilibacillus orientalis XH-63 ${ }^{\mathrm{T}}$ (Carrasco et al., 2006); 4, Gracilibacillus dipsosauri DD1 ${ }^{\mathrm{T}}$ (Wainø et al., 1999); 5, Gracilibacillus halotolerans $\mathrm{NN}^{\mathrm{T}}$ (Wainø et al., 1999). +, Positive; -, negative; ND, no data. All species/strains are positive for acid production from D-glucose and D-mannitol.

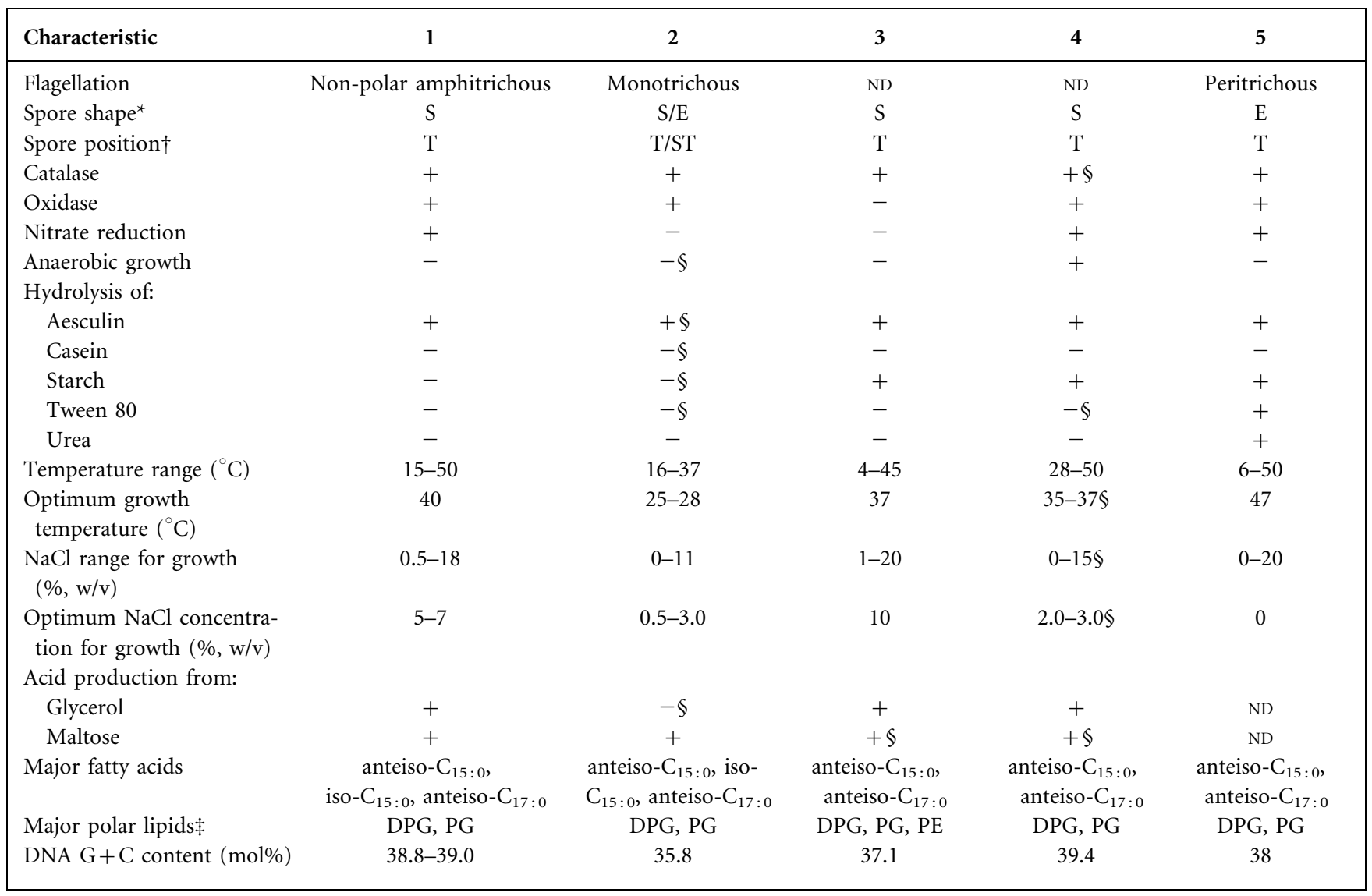

${ }^{\star}$ E, Ellipsoidal; S, spherical.

$\dagger \mathrm{T}$, Terminal; ST, subterminal.

¥DPG, Diphosphatidylglycerol; PE, phosphatidylethanolamine; PG, phosphatidylglycerol.

$\S$ Data from this study.

DNA-DNA hybridization was carried out to evaluate the genomic DNA relatedness between strain $\mathrm{BH} 312^{\mathrm{T}}$ and strain $\mathrm{BH} 314$ using the fluorometric microplate method (Ezaki et al., 1989).

A tree constructed using the NJ method showed that strains $\mathrm{BH} 312^{\mathrm{T}}$ and $\mathrm{BH} 314$ formed a phyletic line with $G$. orientalis XH- $63^{\mathrm{T}}$ with a $66 \%$ bootstrap value within the genus Gracilibacillus (Fig. 1). The overall tree topology of the NJ tree was supported by trees built using the ML and MP algorithms (data not shown). Comparative 16S rRNA gene sequence analysis showed that strain $\mathrm{BH} 312^{\mathrm{T}}$ was most closely related to $G$. orientalis XH- $63^{\mathrm{T}}, \mathrm{G}$. boraciitolerans $\mathrm{T}-16 \mathrm{X}^{\mathrm{T}}, G$. dipsosauri $\mathrm{DD}^{\mathrm{T}}$ and $G$. halotolerans $\mathrm{NN}^{\mathrm{T}}$ with similarities of 96.2, 95.5, 95.1 and $94.2 \%$, respectively, values that are generally sufficient to define a novel species (Rosselló-Mora \& Amann, 2001; Stackebrandt et al., 2002). The 16S rRNA gene sequence similarity between strains $\mathrm{BH} 312^{\mathrm{T}}$ and $\mathrm{BH} 314$ was $97.9 \%$. Therefore, DNA-DNA hybridization was used to evaluate the genomic DNA relatedness between strains $\mathrm{BH} 312^{\mathrm{T}}$ and $\mathrm{BH} 314$; the value obtained was $83 \%$. It was concluded that the DNA-DNA relatedness values were sufficiently high for strains $\mathrm{BH} 312^{\mathrm{T}}$ and $\mathrm{BH} 314$ to be classified as members of a single species (Stackebrandt et al., 2002). Phenotypic properties such as flagellation, spore shape and spore position also supported the view that the isolates were distinguishable from closely related Gracilibacillus species (Table 1). On the basis of the above results, it is proposed that strains $\mathrm{BH} 312^{\mathrm{T}}$ and BH314 should be placed in the genus Gracilibacillus as representatives of a novel species, for which the name Gracilibacillus lacisalsi sp. nov. is proposed.

\section{Description of Gracilibacillus lacisalsi sp. nov.}

Gracilibacillus lacisalsi (la.ci.sal'si. L. masc. n. lacus lake; L. adj. salsus - $a-u m$ salted, salt; N.L. gen. n. lacisalsi of a salt lake). 
Table 2. Fatty acid profiles (\%) of strains $\mathrm{BH} 312^{\top}$ and $\mathrm{BH} 314$ (Gracilibacillus lacisalsi sp. nov.) and related type strains grown on various media

Strains: $1, \mathrm{BH} 312^{\mathrm{T}}$ (this study); 2, BH314 (this study); 3, Gracilibacillus boraciitolerans T-16X ${ }^{\mathrm{T}}$ (Ahmed et al., 2007); 4, Gracilibacillus orientalis XH$63^{\mathrm{T}}$ (Carrasco et al., 2006); 5, Gracilibacillus dipsosauri DD1 ${ }^{\mathrm{T}}$ (Wainø et al., 1999); 6, Gracilibacillus halotolerans $\mathrm{NN}^{\mathrm{T}}$ (Wainø et al., 1999). tr, Trace amount; ND, not detected. Strains were grown as indicated on MA containing 3.5 or $5.0 \%$ (w/v) NaCl and/or on MH agar (Carrasco et al., 2006) containing $10.0 \%(\mathrm{w} / \mathrm{v}) \mathrm{NaCl}$ for 2 days at $35{ }^{\circ} \mathrm{C}$.

\begin{tabular}{|c|c|c|c|c|c|c|c|c|c|}
\hline \multirow[t]{2}{*}{ Fatty acid } & \multicolumn{3}{|c|}{1} & \multicolumn{2}{|c|}{2} & \multirow{2}{*}{$\frac{3}{3.5 \% \mathrm{MA}}$} & \multirow{2}{*}{$\begin{array}{c}4 \\
\mathrm{MH}\end{array}$} & \multirow{2}{*}{$\begin{array}{c}5 \\
\mathrm{MH}\end{array}$} & \multirow{2}{*}{$\begin{array}{c}6 \\
\mathrm{MH}\end{array}$} \\
\hline & $3.5 \%$ MA & $5.0 \%$ MA & MH & $5.0 \% \mathrm{MA}$ & MH & & & & \\
\hline $\mathrm{C}_{14: 0}$ & 1.27 & 1.4 & 0.9 & ND & 0.91 & 0.8 & ND & $\operatorname{tr}$ & $\operatorname{tr}$ \\
\hline $\mathrm{C}_{15: 0}$ & 4.15 & 10.9 & 2.2 & 8.19 & 1.91 & 2.0 & ND & $\operatorname{tr}$ & $\operatorname{tr}$ \\
\hline$C_{16: 0}$ & 10.96 & 9.8 & 12.1 & 7.94 & 16.30 & 5.6 & 4.9 & 7.21 & 9.05 \\
\hline \multicolumn{10}{|l|}{ Branched } \\
\hline iso- $\mathrm{C}_{13: 0}$ & $\mathrm{ND}$ & 0.5 & $\mathrm{ND}$ & ND & ND & $\mathrm{ND}$ & $\mathrm{ND}$ & ND & $\mathrm{ND}$ \\
\hline iso- $\mathrm{C}_{14: 0}$ & 1.14 & 1.1 & $\mathrm{ND}$ & $\mathrm{ND}$ & ND & 0.6 & 1.0 & $\operatorname{tr}$ & 8.96 \\
\hline iso- $\mathrm{C}_{15: 0}$ & 14.42 & 15.1 & 26.6 & 14.43 & 24.74 & 14.5 & 8.5 & 17.57 & 4.19 \\
\hline anteiso- $\mathrm{C}_{15: 0}$ & 39.34 & 36.7 & 28.3 & 39.42 & 27.66 & 50.8 & 51.9 & 39.12 & 56.15 \\
\hline \multicolumn{10}{|l|}{ Unsaturated } \\
\hline $\mathrm{C}_{16: 1} \omega 11 c$ & $\operatorname{tr}$ & ND & 1.0 & 1.37 & 0.97 & $\operatorname{tr}$ & 1.89 & ND & ND \\
\hline
\end{tabular}

Cells form cream, smooth, convex and circular/slightly irregular colonies. Cells are Gram-positive, spore-forming, strictly aerobic rods (approximately $0.2-1.0 \mu \mathrm{m}$ wide and $1.0-2.2 \mu \mathrm{m}$ long) that are motile by means of non-polar amphitrichous flagella. Catalase- and oxidase-positive. Nitrate is reduced to nitrite. A spherical endospore is formed terminally in swollen sporangium. Growth occurs at $15-50{ }^{\circ} \mathrm{C}$ (optimum: $40{ }^{\circ} \mathrm{C}$ ), $\mathrm{pH} 5.5-10.0$ (optimum:

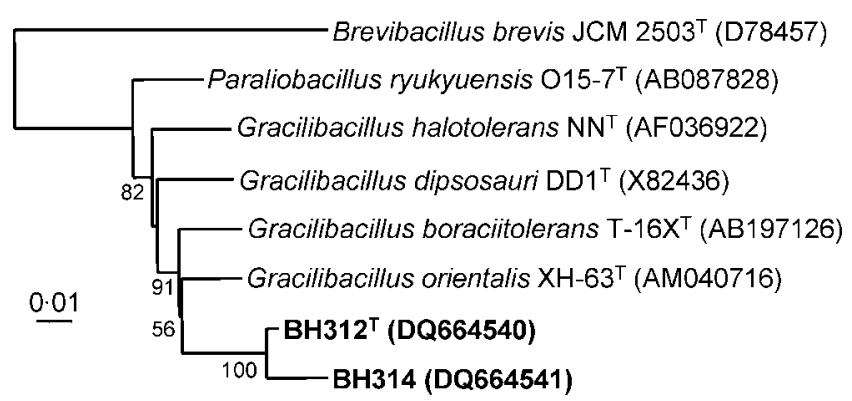

Fig. 1. Neighbour-joining tree showing phylogenetic relationships based on 16S rRNA gene sequences of strains $\mathrm{BH}_{3} 12^{\top}$ and $\mathrm{BH} 314$ and other related taxa. Bootstrap values (percentages of 1000 replicates) greater than $50 \%$ are shown. Brevibacillus brevis JCM $2503^{T}$ was used as an outgroup. Bar, 0.01 changes per nucleotide position.
pH 7.5-8.0) and in 1-18\% (w/v) $\mathrm{NaCl}$ (optimum: 5-7\%). Aesculin is hydrolysed. Hydrolysis of casein, starch, hypoxanthine, Tween 80 , xanthine and urea is not observed. Acids are produced from D-glucose, galactose, sucrose, melibiose, maltose, raffinose, D-fructose, D-mannitol, D-mannose, glycerol, L-arabinose and $\alpha$-D-lactose, but not from inositol. Produces esterase (C4), esterase lipase (C8), naphthol-AS-BI-phosphohydrolase, $\beta$-galactosidase and $\alpha$-glucosidase, but not alkaline phosphatase, lipase (C14), valine arylamidase, cystine arylamidase, trypsin, $\alpha$-chymotrypsin, acid phosphatase, $\alpha$-galactosidase, $\beta$ glucuronidase, $N$-acetyl- $\beta$-glucosaminidase, $\alpha$-mannosidase or $\alpha$-fucosidase. Leucine arylamidase and $\beta$-glucosidase activities are weak. Major isoprenoid quinone is MK-7. Predominant cellular fatty acids are anteiso- $\mathrm{C}_{15: 0}$, iso- $\mathrm{C}_{15 \text { :0 }}$ and anteiso- $\mathrm{C}_{17: 0}$. Contains phosphatidylglycerol, diphosphatidylglycerol and two unidentified phospholipids. DNA $\mathrm{G}+\mathrm{C}$ content is $38.8-39.0 \mathrm{~mol} \%$ (HPLC).

The type strain is $\mathrm{BH} 312^{\mathrm{T}} \quad\left(=\mathrm{KCTC} \quad 13129^{\mathrm{T}}=\mathrm{DSM}\right.$ $\left.19029^{\mathrm{T}}\right)$, isolated from Ai-Ding Lake, Xin-Jiang Province, China.

\section{Acknowledgements}

This work was supported by the 21C Frontier Microbial Genomics and Application Center Program, and by a grant from the hub network establishment for security of foreign biological resources of the global joint R\&D program, Republic of Korea. 


\section{References}

Ahmed, I., Yokota, A. \& Fujiwara, T. (2007). Gracilibacillus boraciitolerans sp. nov., a highly boron-tolerant and moderately halotolerant bacterium isolated from soil. Int J Syst Evol Microbiol 57, 796-802.

Ash, C., Farrow, J. A. E., Wallbanks, S. \& Collins, M. D. (1991). Phylogenetic heterogeneity of the genus Bacillus as revealed by comparative analysis of small-subunit-ribosomal RNA sequences. Lett Appl Microbiol 13, 202-206.

Carrasco, I. J., Márquez, M. C., Yanfen, X., Ma, Y., Cowan, D. A., Jones, B. E., Grant, W. D. \& Ventosa, A. (2006). Gracilibacillus orientalis sp. nov., a novel moderately halophilic bacterium isolated from a salt lake in Inner Mongolia, China. Int J Syst Evol Microbiol 56, 599-604.

Ezaki, T., Hashimoto, Y. \& Yabuuchi, E. (1989). Fluorometric deoxyribonucleic acid-deoxyribonucleic acid hybridization in microdilution wells as an alternative to membrane filter hybridization in which radioisotopes are used to determine genetic relatedness among bacterial strains. Int J Syst Bacteriol 39, 224-229.

Felsenstein, J. (2002). PHYLIP (phylogeny inference package) version 3.6a. Distributed by the author. Department of Genome Sciences, University of Washington, Seattle, USA.

Gomori, G. (1955). Preparation of buffers for use in enzyme studies. Methods Enzymol 1, 138-146.

Jeon, C. O., Lim, J.-M., Lee, J.-M., Xu, L.-H., Jiang, C.-L. \& Kim, C.-J. (2005a). Reclassification of Bacillus haloalkaliphilus Fritze 1996 as Alkalibacillus haloalkaliphilus gen. nov., comb. nov. and the description of Alkalibacillus salilacus sp. nov., a novel halophilic bacterium isolated from a salt lake in China. Int J Syst Evol Microbiol 55, 1891-1896.

Jeon, C. O., Lim, J.-M., Lee, J.-C., Lee, G. S., Lee, J.-M., Xu, L.-H., Jiang, C.-L. \& Kim, C.-J. (2005b). Lentibacillus salarius sp. nov., isolated from saline sediment in China, and emended description of the genus Lentibacillus. Int J Syst Evol Microbiol 55, 1339-1343.

Kimura, M. (1980). A simple method for estimating evolutionary rates of base substitutions through comparative studies of nucleotide sequences. J Mol Evol 16, 111-120.

Komagata, K. \& Suzuki, K. (1987). Lipid and cell-wall analysis in bacterial systematics. Methods Microbiol 19, 161-207.

Lane, D. J. (1991). 16S/23S rRNA sequencing. In Nucleic Acid Techniques in Bacterial Systematics, pp. 115-175. Edited by E. Stackebrandt \& M. Goodfellow. Chichester: Wiley.

Lányí, B. (1987). Classical and rapid identification methods for medically important bacteria. Methods Microbiol 19, 1-67.
Leifson, E. (1963). Determination of carbohydrate metabolism of marine bacteria. J Bacteriol 85, 1183-1184.

Lim, J.-M., Jeon, C. O., Song, S. M. \& Kim, C.-J. (2005). Pontibacillus chungwhensis gen. nov., sp. nov., a moderately halophilic Grampositive bacterium from a solar saltern in Korea. Int J Syst Evol Microbiol 55, 165-170.

Nielsen, P., Rainey, F. A., Outtrup, H., Priest, F. G. \& Fritze, D. (1994). Comparative $16 \mathrm{~S}$ rDNA sequence analysis of some alkaliphilic bacilli and the establishment of a sixth rRNA group within the genus Bacillus. FEMS Microbiol Lett 117, 61-66.

Oren, A. (2002). Diversity of halophilic microorganisms: environments, phylogeny, physiology, and applications. J Ind Microbiol Biotechnol 28, 56-63.

Rosselló-Mora, R. \& Amann, R. (2001). The species concept for prokaryotes. FEMS Microbiol Rev 25, 39-67.

Smibert, R. M. \& Krieg, N. R. (1994). Phenotypic characterization. In Methods for General and Molecular Bacteriology, pp. 607-654. Edited by P. Gerhardt, R. G. E. Murray, W. A. Wood \& N. R. Krieg. Washington, DC: American Society for Microbiology.

Stackebrandt, E. \& Liesack, W. (1993). Nucleic acids and classification. In Handbook of New Bacterial Systematics, pp. 152-189. Edited by M. Goodfellow \& A. G. O’Donnell. London: Academic Press.

Stackebrandt, E., Frederiksen, W., Garrity, G. M., Grimont, P. A., Kämpfer, P., Maiden, M. C., Nesme, X., Rosselló-Mora, R., Swings, J. $\&$ other authors (2002). Report of the ad hoc committee for the reevaluation of the species definition in bacteriology. Int J Syst Evol Microbiol 52, 1043-1047.

Tamaoka, J. \& Komagata, K. (1984). Determination of DNA base composition by reversed-phase high-performance liquid chromatography. FEMS Microbiol Lett 25, 125-128.

Thompson, J. D., Higgins, D. G. \& Gibson, T. J. (1994). CLUSTAL W: improving the sensitivity of progressive multiple sequence alignment through sequence weighting, position-specific gap penalties and weight matrix choice. Nucleic Acids Res 22, 4673-4680.

Ventosa, A., Márquez, M. C., Garabito, M. J. \& Arahal, D. R. (1998). Moderately halophilic gram-positive bacterial diversity in hypersaline environments. Extremophiles 2, 297-304.

Wainø, M., Tindall, B. J., Schumann, P. \& Ingvorsen, K. (1999). Gracilibacillus gen. nov., with description of Gracilibacillus halotolerans gen. nov., sp. nov.; transfer of Bacillus dipsosauri to Gracilibacillus dipsosauri comb. nov., and Bacillus salexigens to the genus Salibacillus gen. nov., as Salibacillus salexigens comb. nov. Int J Syst Bacteriol 49, 821-831. 